\title{
Clinical Evidence and Biomarkers Linking Allergy and Acute or Chronic Rhinosinusitis in Children: a Systematic Review
}

\author{
Eugenio De Corso ${ }^{1,2}$ (D) Daniela Lucidi ${ }^{3}$ Elena Cantone ${ }^{4} \cdot$ Giancarlo Ottaviano $^{5} \cdot$ Tiziana Di Cesare $^{1}$. \\ Veronica Seccia ${ }^{6} \cdot$ Gaetano Paludetti $^{1} \cdot$ Jacopo Galli ${ }^{1}$
}

Accepted: 20 August 2020 / Published online: 5 September 2020

(C) Springer Science+Business Media, LLC, part of Springer Nature 2020

\begin{abstract}
Purpose of the Review We provide a systematic review of experimental and clinical evidences linking allergy to acute, including common cold, and chronic rhinosinusitis in children. Furthermore, we questioned if anti-allergy treatment may prevent the occurrence of rhinosinusitis or improve outcomes of its specific management.

Recent Findings Allergic rhinitis is a common childhood disease in industrialized countries that is responsible for a major impact on quality of life and healthcare resources. Over the years many authors tried to correlate allergy with comorbidities and in particular to the onset of rhinosinusitis including common cold, even though conflicting results are frequently reached. We performed a systematic review in accordance with the Preferred Reporting Items for Systematic Review and Meta-Analysis (PRISMA) process. Our search yielded 7103 that were finally screened. This resulted in 25 publications of which the full texts were assessed and included in a qualitative analysis per different phenotypes of rhinosinusitis.

Summary The evidence suggests that allergy may lead to overall impairment of mechanical and immunological defense function of the nasal mucosa against viruses and that anti-allergy treatment may significantly decrease the number and severity of upper respiratory tract infections including common colds in children. It was not possible to perform the analysis for allergy and postviral acute rhinosinusitis, bacterial acute rhinosinusitis, and recurrent acute rhinosinusitis because of paucity and heterogeneity of data. Although there is no definitive proof of causation linking allergy to chronic rhinosinusitis, studies lead to suppose that antiallergy treatment may improve outcomes of specific CRS treatments.
\end{abstract}

Keywords Allergy $\cdot$ Rhinovirus $\cdot$ Coronavirus $\cdot$ Common cold $\cdot$ Acute rhinosinusitis $\cdot$ Chronic rhinosinusitis $\cdot$ Children

\section{Introduction}

Allergic rhinitis (AR) in children has a significant impact on global quality of life, including school performance, sleep disorders, and emotional health [1]. AR is a nasal mucosa

This article is part of the Topical Collection on Rhinosinusitis

Eugenio De Corso

eugenio.decorso@policlinicogemelli.it

1 Department of Head and Neck Surgery - Otorhinolaryngology, Fondazione policlinico Universitario A. Gemelli IRCCS. Università Cattolica del Sacro Cuore, Rome, Italy

2 Department of Head and Neck Surgery, “A. Gemelli” Hospital, Division of rhinology - Institute of Otorhinolaryngology, Catholic University School of Medicine and Surgery, Largo A. Gemelli n.1, 00168 Rome, Italy inflammatory condition caused by environmental allergens interacting with immunoglobulin (Ig) E in sensitized subjects. Repeated exposure may lead to long-term changes in systemic and local inflammation, including upregulation of nasal eosinophils and allergen-specific IgE, increased levels of adhesion

3 Department of Otolaryngology-Head and Neck Surgery, University Hospital of Modena, Modena, Italy

4 Department of Neuroscience, Reproductive and Odontostomatological Sciences, ENT section, University "Federico II", Naples, Italy

5 Department of Neurosciences, Otolaryngology Section, University of Padova, Padova, Italy

6 Otolaryngology Audiology, and Phoniatric Operative Unit. Department of Surgical, Medical, Molecular Pathology, and Critical Care Medicine. Azienda Ospedaliero Universitaria Pisana, University of Pisa, Pisa, Italy 
molecules in airway mucosa, and enhanced systemic response to allergen challenge [2]. Consequently, it is not surprising that AR has been historically associated with comorbid upper airway diseases [3]. Herein, we review clinical and laboratory evidence, linking allergy to rhinosinusitis in children. We aimed to investigate allergy not only as etiologic but also as a worsening factor; in fact, poorly controlled AR might contribute to exacerbations and as such its adequate treatment might improve outcomes [4].

\section{Material and Methods}

\section{Search Strategy}

This systematic review was conducted in accordance with the Preferred Reporting Items for Systematic Review and MetaAnalysis (PRISMA) process to identify published experimental and clinical articles about allergy and rhinosinusitis including common cold in children. Manuscript were screened primarily by Ovid Medline and EMBASE and from other sources (PubMed Central, Cochrane review, Web of Science, and Google Scholar) and published from January 2000 to April 2020. Only 3 articles before this date were included because they were considered particularly relevant for this systematic review. Literature searches were performed in April 2020.

We performed two different searches using MeSH terms. One group of authors focused on experimental studies matching the term as follows: [(rhinovirus) OR (coronavirus) OR (epithelial barrier) OR (epithelial cells) OR (barrier function) OR (nasal epithelial cells) OR (viral infections)] AND [(allergy) OR (allergic rhinitis) OR (atopy) OR (atopic) OR (allergic children) OR (non-allergic children) OR (immunoglobulin E)] AND [(children) OR (childhood) OR (pediatric)]. The second group of authors focused on clinical studies, matching the term as follows: [(respiratory infections) OR (acute rhinosinusitis) OR (chronic rhinosinusitis) OR (sinusitis) OR (rhinosinusitis) OR (recurrent sinusitis) OR (endoscopic sinus surgery) OR (URTI) OR (upper recurrent respiratory infection) OR (common cold)] AND [(allergy) OR (allergic rhinitis) OR (atopy) OR (atopic) OR (allergic children) OR (non-allergic children) OR (immunoglobulin E) OR (immunotherapy) OR (antihistamine)) AND ((children) OR (childhood) OR (pediatric)].

\section{Study Selection}

In the first screening, authors read the title and abstract of the articles selecting those being as inclusive as possible. The abstracts were screened independently by reviewers of the two groups. Any disagreements were resolved by consensus. Inclusion and exclusion criteria were established before the selection of relevant studies. The inclusion criteria were primary research (including descriptive studies, observational studies, randomized trials, and basic science articles), published after January 2000, addressing allergy and rhinosinusitis in children including common cold. Furthermore, we questioned if anti-allergy treatment may prevent the occurrence of rhinosinusitis or improve its specific management.

We excluded secondary research studies (e.g., review articles or systematic review), case studies, newspaper article, lecture, letter, comment, personal narrative, consensus conference, and editorial. Only articles with full text available were included. Additional studies were manually identified from the reference lists of retrieved literature. We excluded all the article that did not meet the inclusion criteria or deal directly with the issue investigated. Based on our review, it was not possible to differentiate between atopy or sensitization and allergy. We included only English-language peer-reviewed papers.

\section{Results and Discussion}

The details of the systematic search performed are shown in Fig. 1. In total, our search yielded 9870 articles after duplicates removal. We excluded 2767 articles due to time of publication and type of article, and then 7103 were finally screened. This resulted in 25 publications of which the full texts were assessed and included in a qualitative analysis. We summarized in tables the included studies per phenotype classifying evidence using GRADE methodology. No studies were included in a quantitative synthesis (meta-analysis).

\section{Allergy and Acute Rhinosinusitis in Children}

According to the EPOS2020 guidelines [5], acute rhinosinusitis (ARS) in children is defined as a sudden onset of two or more of the following symptoms: nasal blockage/ obstruction/congestion, discolored nasal discharge, and cough (daytime and night time) for $<12$ weeks. ARS in children can theoretically be divided into viral acute rhinosinusitis (i.e., common cold), post-viral rhinosinusitis, and acute bacterial rhinosinusitis (ABRS). Acute viral rhinosinusitis has usually a duration of symptoms of $\leq 10$ days. Post-viral one is defined if symptoms increase after 5 days or are persistent for $>$ 10 days, with less than 12 weeks duration; only small subgroups of these are of bacterial origin. Discolored mucous, severe pain, fever $>38^{\circ} \mathrm{C}$, and "double sickening" lead to the suspicious of bacterial supra infection. Recurrent ARS (RARS) is defined as $\geq 4$ episodes of rhinosinusitis per year with symptom-free intervals. 
Fig. 1 Flowchart of article search and selection

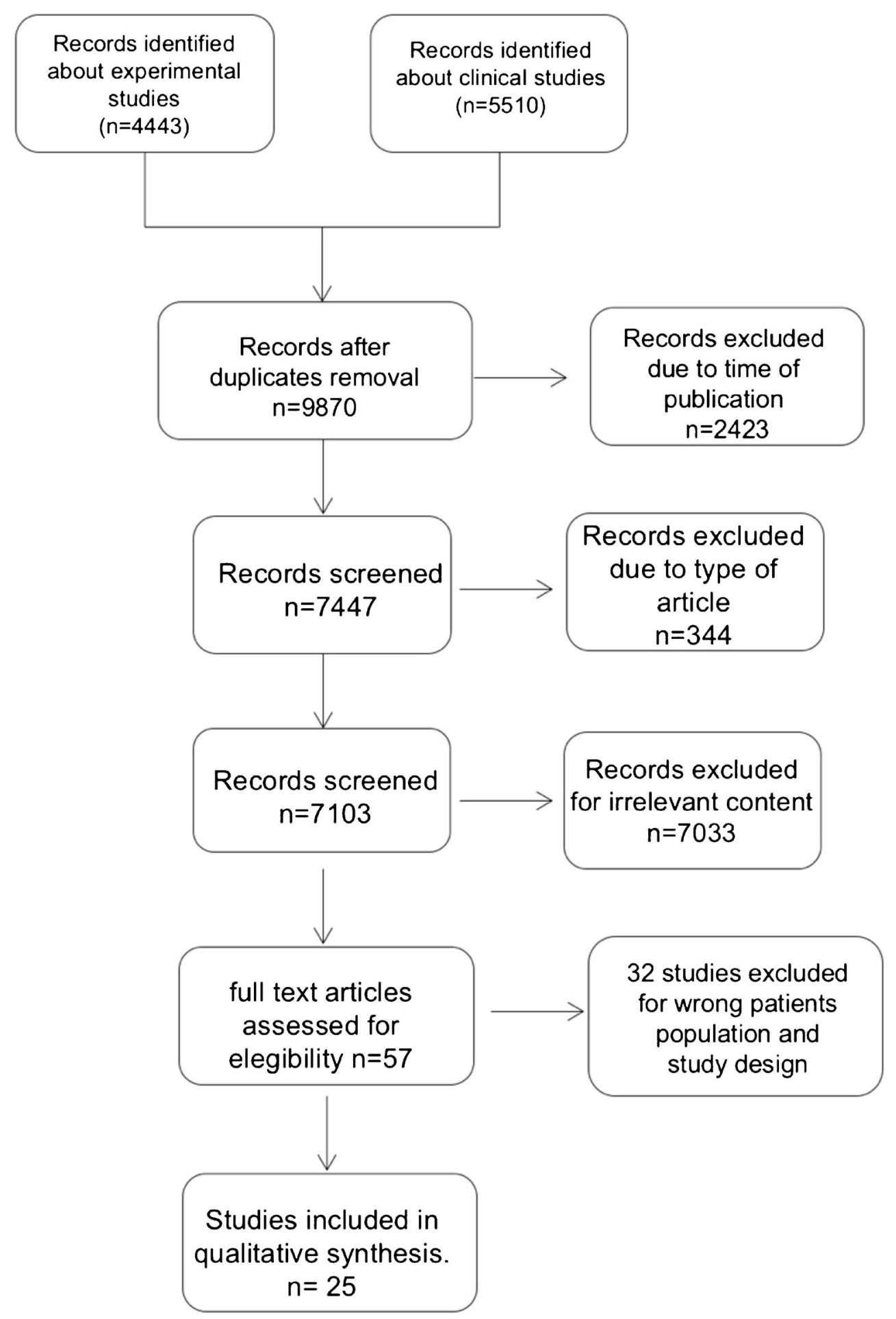

\section{Allergy and Acute Viral Rhinosinusitis in Children (i.e., Common Cold) Including Viral Upper Respiratory Tract Infections (URTIs)}

Viral acute rhinosinusitis (i.e., common cold) may be induced in children by a wide variety of viruses, such rhinoviruses $(\mathrm{RV})$ and coronaviruses $(\mathrm{CoV})$, as well as respiratory syncytial virus (RSV), parainfluenza viruses, and adenoviruses. The common cold is the most frequent upper respiratory tract infection (URTI), which is the most commonly treated acute problem in primary pediatric care [6]. URTI are caused mainly by viruses and may involve not only the nose and sinuses but also the pharynx, larynx, and large airways. Clinical expression of URTIs is variable, and it is influenced 
by the nature of the infecting virus, by the age, and by physiological state and immunological experience of the host. Sino nasal clinical features of common cold or URTI commonly overlap and are characterized by self-limiting irritation of the upper airways with associated cough with no proof of pneumonia [7]. Based on our review of the literature, we observed that authors for research purpose include common colds in URTI; for this reason, we included both papers about allergy and common cold or URTI.

\section{Laboratory Evidences and Biomarkers Linking Allergy to Increased Risk of Viral Acute Rhinosinusitis}

Allergy may induce inflammation of the nasal mucosa leading to impairment of epithelial barrier function and secondary deficiency of early local immune reaction. Several studies demonstrated, in fact, that the upper airway epithelium represents not only a mechanical wall against pathogens by mucociliary clearance but also an immunological barrier modulating the innate immune response through cytokine production $[8,9]$.

Interestingly, authors $[10,11]$ demonstrated impairment of the overall mechanical function of the epithelium and, in particular, decreased expression of tight-junction proteins occludin and zonula occludens- 1 in cultured epithelial nasal cells from allergic patients. Steelant et al. [12] demonstrated that nasal secretions from allergic subjects rapidly decrease the trans-tissue resistance of epithelial cell cultures in vitro. They also showed that anti-IL-4 treatment in mice prevented epithelial barrier disruption. Finally, several authors have demonstrated $[13,14]$ that allergy may expedite viral overcome of mechanical barriers because Th2-polarized cytokines such as IL-4, IL-5, and IL-13 can upregulate endothelial and epithelial expression of adhesion molecules like intercellular adhesion molecule-1 (ICAM-1), which is the receptor for $90 \%$ of rhinoviruses.

On the other hand, several authors demonstrated that allergy may modify the immunological functions of the epithelia. Many studies showed the deficiency of the innate immune response in allergic mucosa of upper and lower respiratory epithelia cells. Furthermore, it has been demonstrated in the lab that interferon production may be defective in allergic patients. Interferons are crucial for induction of apoptosis in virus-infected host cells because they prevent establishment of viral replication and promote phagocytosis of infected cells [15-17].

The majority of experimental studies about this topic used cultured epithelial cells obtained from adults, and for this reason, they were not included in the qualitative analyses. The only article included was of Teach et al. [18] reporting that peripheral blood mononuclear cells cultured from a subset of atopic children treated with anti-IgE improved INF- $\alpha$ production after incubation with rhinovirus (Table 1).

\section{Clinical Evidence Linking Allergy to Risk of Viral Upper Respiratory Infection}

From a clinical point of view, the results are more controversial than those from the laboratory. Studies in the literature comparing the incidence of upper respiratory infections between allergic and non-allergic subjects are relatively few in number. We found 3 retrospective and 1 prospective article that were included in the qualitative analyses (Table 2).

In two manuscripts, it has been demonstrated that atopic/ allergic patients had increased susceptibility to upper respiratory infections. In 2006, in a large cross-sectional survey, Karevold et al. [19] demonstrated that atopy increases the risk of developing upper and lower respiratory tract infections in children. In particular, atopy was the strongest risk factor, such as in the home environment (dampness). Accordingly, Ciprandi et al. [20] in a prospective study observed that allergic children have a significantly higher number of upper respiratory infections, more serious in duration and severity, compared with non-allergic children.

Other authors disagree; Kværner et al. [21] reported that correlation between upper respiratory infection and atopic diseases from a population-based sample of 7992 Norwegian twins was weak, even though results were inconclusive. Sütçü et al. [22] confirmed that the number of episodes per year was not significantly different between atopic and healthy children, even though atopic ones had longer episodes of recurrent URTI compared to controls.

Interestingly all clinical studies included in the qualitative analyses about therapy (Table 2) supported the hypothesis that anti-allergy-specific or non-specific treatments may prevent viral infections of the upper airways. Antihistamine therapy can act by reducing the expression of adhesion viral receptors to modulate the production of Th2-related interleukins [20]. Authors [14, 23] demonstrated that children treated with cetirizine had a significant reduction in ICAM-I expression on epithelial cells, thus preventing possible relapse of rhinovirus infections and diminishing both the number and severity of recurrent respiratory infections in children. Barberi et al. [24••, 25] demonstrated that children treated with sublingual immunotherapy (SLIT) had significantly fewer respiratory infections (RI) than symptomatically treated children. In addition, SLIT-treated children had less fever episodes per year and took fewer medications vs. symptomatically treated children.

\section{Allergy and Post-Viral Acute Rhinosinusitis and Acute Bacterial Rhinosinusitis (ABRS) in Children}

In the articles reviewed, we did not find manuscript in which authors distinguished between post-viral ARS and ABRS. Authors focused the attention particularly on the risks of bacterial superinfection. Recent evidence suggests 
Table 1 Laboratory evidence linking allergy to allergy to increased risk of viral acute rhinosinusitis

Evidence from the lab linking allergy to allergy to increased risk of viral acute rhinosinusitis

\begin{tabular}{|c|c|c|c|c|c|}
\hline $\begin{array}{l}\text { Author } \\
\text { Year (ref) }\end{array}$ & No. of cases, age & Experimental models & Methods & Relevant results & $\begin{array}{l}\text { Association } \\
\text { (Level of } \\
\text { evidence) }\end{array}$ \\
\hline $\begin{array}{l}\text { Teach et al. } 2015 \\
\text { [20] }\end{array}$ & $\begin{array}{l}N=478 \text { children } \\
\quad(10.2 \pm 2.93 \text { years })\end{array}$ & $\begin{array}{l}\text { Peripheral blood } \\
\text { mononuclear } \\
\text { cell cultures } \\
\text { incubated } \\
\text { ex-vivo with } \\
\text { rhinovirus }\end{array}$ & $\begin{array}{l}\text { Measuring IFN- } \alpha \text { in } \\
\text { supernatants of } \\
\text { PBMCs } \\
\text { cultures obtained } \\
\text { from a } \\
\text { subset of subjects } \\
(n=87) \\
\text { incubated ex vivo } \\
\text { with } \\
\text { rhinovirusin patients } \\
\text { treated } \\
\text { or not with } \\
\text { omalizumab }\end{array}$ & $\begin{array}{l}\text { The group treated with anti-IgE } \\
\text { had improved IFN- } \alpha \\
\text { production } \\
\text { after virus infection suggesting } \\
\text { restoring of the impaired } \\
\text { interferon } \\
\text { response and increasing } \\
\text { antiviral } \\
\text { immunity and suggesting that } \\
\text { anti-IgE } \\
\text { may prevent upper and lower } \\
\text { respiratory } \\
\text { infections and asthma } \\
\text { exacerbations }\end{array}$ & $\begin{array}{l}\text { Yes } \\
\text { (Level V) }\end{array}$ \\
\hline
\end{tabular}

$P B M C$, peripheral blood mononuclear cell; $I N F-\alpha$, interferon alpha

in fact that damage or disruption of mucociliary function due to viral infection is probably a major cause of super or secondary bacterial infection. Allergy is a condition that potentially can exacerbate an inflammatory sinonasal response, although very limited data are available to confirm this hypothesis in children [26]. Based on paucity and heterogeneity of the studies, it was not possible to perform a qualitative analysis linking allergy to ABRS or to post-viral ARS [5]. For this reason herewith, we report available data by a narrative description.

Lin et al. [27] demonstrated that the prevalence of colonization by methicillin-resistant $S$. aureus was higher in atopic children than healthy ones and that atopic children were more likely to develop ARS than non-atopic ones. Interestingly, other authors [28] observed that AR was highly prevalent in orbital ARS complications in children and, specifically, it was found in $64.3 \%$ of children with pre-septal cellulitis, in $25 \%$ with periostitis, and in $76.5 \%$ with subperiosteal abscess. Furthermore, the prevalence of AR was significantly higher in patients presenting in pollen season from February to August than in patients presenting between September and January. The authors suggested that allergy may be a cofactor in the pathogenesis of orbital complication of ARS. In addition, Alho et al. [29] observed that subjects with allergic IgE-mediated rhinitis had more severe paranasal sinus changes in CT scans than non-allergic subjects during viral colds. The authors suggested that these changes were signs of more severely impaired sinus function, increasing the risk of bacterial sinusitis.

Shi-Wei Lin et al. [30] recently evaluated the risk of incident ARS among children with allergic rhinitis, using a nationwide, population-based health claims research database and including a large number of patients. The authors observed that the risk of ARS was significantly higher in pediatric patients with allergic rhinitis compared with those without the condition (adjusted hazard ratio $=3.03,95 \%$ confidence interval $=2.89-3.18$ ) . Caution is advised when interpreting the findings of the authors due to limitations of the study: retrospective design and diagnosis of ARS based on clinical history (authors could not confirm bacterial etiology of sinusitis).

On the other hand, Leo et al. [31] demonstrated that children with grass pollen-induced rhinitis during exposure to pollen had an incidence of endoscopic confirmed ARS comparable with non-allergic children; they consequently suggested that AR was a negligible risk factor for ARS and that the most common risk factor was instead a previous acute viral infection. Accordingly, EPOS 2020 concluded that there appears to be small evidence to support the presence of AR as a risk factor for developing ARS in children, recognizing a central role for previous viral infection.

\section{Allergy and Recurrent Acute Rhinosinusitis (RARS) in Children}

We found very limited and heterogeneous data linking allergy to RARS, and it was not possible to perform a qualitative analysis. Choi et al. [32] evaluated the predisposing factors that may be associated with chronic and recurrent RS examining 296 patients with RS younger than 13 years of age. The prevalence of allergic rhinitis, atopy, and asthma was significantly higher in patients with chronic and recurrent RS than 
Table 2 Articles investigating clinical association between allergy and upper respiratory infections

Clinical evidence linking allergy to risk of upper respiratory tract infections

\begin{tabular}{|c|c|c|c|c|c|}
\hline $\begin{array}{l}\text { Author } \\
\text { Year } \\
\text { (ref) }\end{array}$ & Type of article & $\begin{array}{l}\text { No. of cases (mean } \\
\text { age) }\end{array}$ & Methods & Relevant results & $\begin{array}{l}\text { Association } \\
\text { (Level of } \\
\text { evidence) }\end{array}$ \\
\hline $\begin{array}{l}\text { Karevold } \\
\text { et al. } \\
2006 \\
{[19]}\end{array}$ & $\begin{array}{l}\text { Cross-sectional } \\
\text { survey }\end{array}$ & $\begin{array}{l}N=5125 \\
\quad(10 \text { years })\end{array}$ & $\begin{array}{l}\text { Assess co-morbidity and risk factors for } \\
\text { recurrent upper and lower respiratory } \\
\text { infections }\end{array}$ & $\begin{array}{l}\text { Atopic disease was a constitutional risk } \\
\text { factor, for upper and lower airway } \\
\text { infections }\end{array}$ & $\begin{array}{l}\text { Yes } \\
\text { (Level IV) }\end{array}$ \\
\hline $\begin{array}{l}\text { Ciprandi } \\
\text { et al. } \\
2009 \\
{[20]}\end{array}$ & Prospective study & $\begin{array}{l}N=117 \\
\quad(4.02 \pm \\
\quad 1.0 \text { years }) ; 46 \\
\text { allergic }\end{array}$ & $\begin{array}{l}\text { Evaluate the number and duration of RI } \\
\text { in allergic and non-allergic children }\end{array}$ & $\begin{array}{l}\text { Allergic children showed a significantly } \\
\text { higher number (mean } 1.26 \pm 0.73) \\
\text { and longer duration of RI ( } 8.92 \text { days) } \\
\text { in comparison with non-allergic } \\
\text { group }(0.94 \pm 1.37 \text { and } 4.85 \text { days) }\end{array}$ & $\begin{array}{l}\text { Yes } \\
\text { (Level II) }\end{array}$ \\
\hline $\begin{array}{l}\text { Kværner } \\
\text { et al. } \\
1996 \\
\text { [21] }\end{array}$ & $\begin{array}{l}\text { Retrospective } \\
\text { analysis }\end{array}$ & $\begin{array}{l}N=7992(\text { mean } \\
\quad \text { age not known })\end{array}$ & $\begin{array}{l}\text { Estimate comorbidity between ear } \\
\text { infections, tonsillitis, sinusitis and } \\
\text { related childhood diseases }\end{array}$ & $\begin{array}{l}\text { The correlation between the infectious } \\
\text { and atopic diseases was weak }\end{array}$ & $\begin{array}{l}\text { Inconclusive } \\
\text { (Level IV) }\end{array}$ \\
\hline $\begin{array}{l}\text { Sütçü } \\
\quad \text { et al. } \\
2016 \\
{[22]}\end{array}$ & $\begin{array}{l}\text { Retrospective } \\
\text { analysis }\end{array}$ & $\begin{array}{l}N=507 \text { children } \\
\quad(46, \text { range } \\
\quad 4-190, \text { months })\end{array}$ & $\begin{array}{l}\text { Evaluate children presenting with the } \\
\text { complaint of recurrent infections and } \\
\text { to determine the possible predictive } \\
\text { factors }\end{array}$ & $\begin{array}{l}\text { Atopic children had longer episodes of } \\
\text { recurrent URTI compared to controls; } \\
\text { however, the number of episodes per } \\
\text { year was not significantly different }\end{array}$ & $\begin{array}{l}\text { No } \\
\text { (Level IV) }\end{array}$ \\
\hline
\end{tabular}

Role of anti-allergy treatment in preventing upper respiratory infections

\begin{tabular}{|c|c|c|c|c|c|}
\hline $\begin{array}{c}\text { Ciprandi } \\
1999 \\
{[20]}\end{array}$ & $\begin{array}{l}\text { Double-blind and } \\
\text { placebo-- } \\
\text { controlled study }\end{array}$ & $\begin{array}{l}N=20 \text { children } \\
\text { with allergy; } \\
10 \text { terfenadine } \\
\text { group } \\
(8.5 \pm 3 \text { years }) \\
10 \text { placebo } \\
(7.9 \pm 2.7 \text { years })\end{array}$ & $\begin{array}{l}\text { Continuous terfenadine }(1 \mathrm{mg} / \mathrm{kg} \text { per } \\
\text { body weight per day) vs placebo for } \\
1 \text { year. Outcome: Symptoms; } \\
\text { inflammatory cells and ICAM-1 } \\
\text { measured by nasal scraping }\end{array}$ & $\begin{array}{l}\text { Terfenadine treatment reduces ICAM-1 } \\
\text { expression on nasal epithelial cells; } \\
\text { children treated with terfenadine had } \\
\text { significantly fewer extra visits and } \\
\text { school absences than the placebo } \\
\text { group }\end{array}$ & $\begin{array}{l}\text { Yes } \\
\text { (Level I) }\end{array}$ \\
\hline $\begin{array}{l}\text { Fasce } \\
\quad 1996 \\
{[14]}\end{array}$ & $\begin{array}{l}\text { Double-blind, } \\
\text { placebo } \\
\text { controlled } \\
\text { randomized } \\
\text { study }\end{array}$ & $\begin{array}{l}\mathrm{N}=20 \text { children } \\
(5-14 \text { years } \\
\text { old) with mite } \\
\text { allergy }\end{array}$ & $\begin{array}{l}\text { Cetirizine vs placebo for } 15 \text { days. Nasal } \\
\text { scrapings were performed to evaluate } \\
\text { inflammatory cell infiltration and } \\
\text { ICAM-I expression on epithelial cells }\end{array}$ & $\begin{array}{l}\text { Cetirizine-treated children showed a } \\
\text { significant reduction (or even total } \\
\text { absence) of ICAM-I expression on } \\
\text { epithelial cells }(p=0.002) \text { and a } \\
\text { reduction trend in inflammatory cell } \\
\text { counts compared with placebo }\end{array}$ & $\begin{array}{l}\text { Yes } \\
\text { (Level I) }\end{array}$ \\
\hline $\begin{array}{l}\text { Barebri } \\
2015 \\
{[25]}\end{array}$ & $\begin{array}{l}\text { Prospective case } \\
\text { control } \\
\text { observational } \\
\text { study, not } \\
\text { randomized }\end{array}$ & $\begin{array}{l}N=40 \text { HDM } \\
\quad \text { allergic children } \\
\quad(9.3 \text { years })\end{array}$ & $\begin{array}{l}\text { Patients were subdivided in } 2 \text { groups: } 20 \\
\text { treated by symptomatic drugs and } 20 \\
\text { by high-dose HDM-SLIT }\end{array}$ & $\begin{array}{l}\text { SLIT-treated children had significantly } \\
(p=0.01) \text { less RI episodes (3.5) than } \\
\text { control group }(5.45)\end{array}$ & $\begin{array}{l}\text { Yes } \\
\text { (Level II) }\end{array}$ \\
\hline $\begin{array}{l}\text { Barberi } \\
2018 \\
{[24]}\end{array}$ & $\begin{array}{l}\text { Retrospective } \\
\text { analysis }\end{array}$ & $\begin{array}{l}N=33 \text { HDM } \\
\quad \text { allergic children } \\
\quad(9.3 \text { years })\end{array}$ & $\begin{array}{l}\text { Investigate whether } 3 \text { year high-dose } \\
\text { HDM-SLIT affects respiratory } \\
\text { infections in children with allergic } \\
\text { rhinitis }\end{array}$ & $\begin{array}{l}\text { SLIT-treated children had significantly } \\
\text { fewer RI episodes than } \\
\text { symptomatically treated children. In } \\
\text { addition, they had less fever and took } \\
\text { fewer medications, such as antibiotics } \\
\text { and antipyretics }\end{array}$ & $\begin{array}{l}\text { Yes } \\
\text { (Level IV) }\end{array}$ \\
\hline
\end{tabular}

$H D M$, house dust mites; SLIT, sub-lingual immunotherapy; URTI, upper respiratory tract infections; $R I$, respiratory infections; ICAM, intercellular adhesion molecule

those with acute and subacute RS. Veskitkul et al. [33] evaluated the clinical characteristics and predisposing factors of RARS in children as well as the preventive therapy. The authors detected allergy in $35.1 \%$ of cases and suggested that children with RARS should be always evaluated for the presence of underlying predisposing conditions including allergic disease. Nevertheless, no comparison with a control group was performed, and for this reason, data are not definitely supporting a link between allergy and RARS.

\section{Allergy and Chronic Rhinosinusitis (CRS) in Children}

Chronic rhinosinusitis (with or without nasal polyps) in children is defined as presence of two or more symptoms, one of 
which should be either nasal blockage/obstruction/congestion or nasal discharge (anterior/posterior nasal drip) with or without facial pain/pressure and/or cough for $\geq 12$ weeks associated with pathognomonic endoscopic signs or CT changes [5]. The prevalence of CRS in children is lower than in adults (2$4 \%$ ), nevertheless, the negative impact on quality of life seems to be similar to that observed in adults. Studies on CRS in children are less common, and it is more difficult to investigate the relationship with allergy [5]. Several factors contribute to complicate the analyses including incomplete evaluation (nasal endoscopy and/or imaging are rarely performed in many children) and the difficulty to differentiate CRS from adenoid hypertrophy, adenoiditis, and (allergic) rhinitis. In fact, nasal blockage may occur in AR children, due to edematous mucosa, neurogenic and vascular responses, overproduction of secretions, and impaired mucociliary clearance leading to congestion of the ostia and symptoms simulating rhinosinusitis. On the other hand, the blockage leads to stagnant debris and acidotic environment that might stimulate bacteria overgrowth [34, 35].

Histopathological analysis [36, 37] demonstrated that pediatric CRS is quite different from the adult form, showing greater inflammatory cellularity, higher density of submucosal lymphocytes, less eosinophilic inflammation, basement membrane thickening, and mucous gland hyperplasia, suggesting a different pathway compared with the adult CRS pattern, which is predominantly characterized by a Th2-oriented response with polypoid changes. The presence of nasal polyps in a pediatric patient should suggest the hypothesis of cystic fibrosis that has not been included in this paper. More specifically, some evidence supports the hypothesis that CRS in children over the age of 13 seems to be based more on eosinophilic inflammation, while under this age, CRS seems to be based more on neutrophilic inflammation, thus justifying the lower prevalence of nasal polyps in children than in adult [36, 37].

Several manuscripts support the hypothesis that AR and CRS could be different faces of the same disease. AR, in fact, is typically characterized by a Th2 immune response involving IL-4, IL-5, and IL-13 which drives IgE production and recruitment of eosinophil granulocytes. It has been suggested [38-42] that eosinophils, by generating potent toxic agents (cationic proteins, oxygen-free radicals, and proinflammatory cytokines), may play a major role in initiating and perpetuating inflammation of sinonasal mucosa in patients with AR.

\section{Evidence from the Lab and Biomarkers Linking Allergic Inflammation to Increased Risk of Chronic Rhinosinusitis in Children}

All studies included in a qualitative analysis support a specific link between CRS and AR in children (Table 3). Chawes [43] studied nasal eosinophilia and nasal airway patency (assessed by acoustic rhinometry) in children with AR, non-allergic rhinitis, and healthy controls. Nasal eosinophilia and irreversible nasal airway obstruction were significantly associated with AR, while there was no such association with non-allergic rhinitis. The authors suggested that chronic inflammation and structural remodeling of the sinonasal mucosa may occur in allergic children even at 6 years of age.

Some authors suggested that allergic sinonasal inflammation may support bacterial infection. Blair et al. [44] in an animal model showed that allergic inflammatory reaction may obstruct sinus drainage encouraging bacterial infection into the maxillary sinus. Shin et al. [45] demonstrated that total IgE, total eosinophil count, and serum eosinophil cationic protein levels were significantly higher in CRS children whose symptoms and radiologic abnormalities did not resolve after 12 weeks despite appropriate antibiotic therapy (nonresponder) compared with responders and healthy controls. Moreover, AR in children may affect the efficiency of mucociliary clearance, which is one of the most important protective functions of the respiratory epithelium. Deterioration of mucociliary system appears to be related to more severe rhinitis with a higher intensity of local nasal inflammation, reflected in nasal smear eosinophilia [46••].

Brożek-Mądry and co-workers [47] evaluated the relation between bacterial strains and cytological examination of nasal mucosa in children with CRS; they found that the most common strains of bacteria observed in CRS (Hemophilus influenzae, Moraxella catarrhalis, and Staphylococcus aureus) were associated with a higher prevalence of atopy and percentage of eosinophils in cytology. It must be noted that $S$. aureus enterotoxins are able to induce increased severity of the disease, amplifying eosinophilic inflammation in atopic patients [48].

\section{Clinical Evidences Linking Allergic Inflammation to Increased Risk of Chronic Rhinosinusitis}

The association between allergy and CRS in adults has been discussed for years and a strong association has been observed with particular subtypes of CRS with nasal polyps (CRSwNP), such as central compartment atopic disease and allergic fungal rhinosinusitis (AFRS) [49, 50]. Manuscripts on pediatric CRS are less common predominantly because of ethical issues regarding administration of X-rays in the pediatric population. The publications included in the qualitative analyses are summarized in Table 4 . Conclusions of the studies included in the qualitative analyses were not unanimously linking allergy to chronic rhinosinusitis.

Several manuscripts seem to support a positive clinical association between AR and CRS, describing a prevalence varying between 27 and $59 \%$ of patients [51-53]. Brietzke et al. [54] in an expert panel consensus suggested that there is a clinically relevant association between AR and pediatric 
Table 3 Evidence of inflammatory cells and mediators linking allergy to chronic rhinosinusitis in children

Biomarkers linking allergy to risk of CRS

\begin{tabular}{|c|c|c|c|c|c|}
\hline $\begin{array}{l}\text { Author } \\
\text { Year } \\
\text { () ref }\end{array}$ & No. of cases & $\begin{array}{l}\text { Experimental } \\
\text { models }\end{array}$ & Methods & Relevant results & $\begin{array}{l}\text { Association } \\
\text { (Level of } \\
\text { evidence) }\end{array}$ \\
\hline $\begin{array}{l}\text { Chawes, } 2011 \\
\text { [43] }\end{array}$ & $\begin{array}{l}N=411 \text { children with } \\
\text { AR, non-AR and } \\
\text { healthy controls } \\
\text { ( } 6 \text { years })\end{array}$ & $\begin{array}{l}\text { Nasal airway } \\
\text { patency was } \\
\text { assessed by } \\
\text { acoustic } \\
\text { rhinometry }\end{array}$ & $\begin{array}{l}\text { Acoustic rhinometry was performed } \\
\text { twice in the child's } 6 \text { th year of life, } \\
\text { with or without allergy. Nasal } \\
\text { eosinophilia was assessed by nasal } \\
\text { scraping }\end{array}$ & $\begin{array}{l}\text { Nasal eosinophilia correlated with } \\
\text { irreversible nasal airway } \\
\text { obstruction, in allergic children } \\
\text { already at age } 6 \text { years. No change } \\
\text { in nasal airway patency were } \\
\text { observed in non-allergic rhinitis }\end{array}$ & $\begin{array}{l}\text { Yes } \\
\text { (Level III) }\end{array}$ \\
\hline $\begin{array}{l}\text { Blair et al. } \\
2001[44]\end{array}$ & N/A & $\begin{array}{l}\text { Mouse } \\
\text { sensitized to } \\
\text { ovalbumin } \\
\text { by } \\
\text { intraperito- } \\
\text { neal } \\
\text { injection }\end{array}$ & $\begin{array}{l}\text { Sinuses of the mouse were infected by } \\
\text { S. pneumoniae, with or without } \\
\text { concomitant administration of } \\
\text { ovalbumin to induce or not allergic } \\
\text { inflammation }\end{array}$ & $\begin{array}{l}\text { Mice with allergic sinonasal } \\
\text { inflammation had significantly } \\
\text { more bacteria and significantly } \\
\text { more inflammation (as indicated by } \\
\text { neutrophil, eosinophil, and } \\
\text { mononuclear influx) into the sinus } \\
\text { with respect to the non-allergic } \\
\text { ones }\end{array}$ & $\begin{array}{l}\text { Yes } \\
\text { (Level V) }\end{array}$ \\
\hline $\begin{array}{l}\text { Shin et al. } \\
2015 \text { [45] }\end{array}$ & $\begin{array}{l}N=36 \text { CRS } \\
\text { responders vs } 22 \\
\text { CRS } \\
\text { non-responders, } 22 \\
\text { healthy controls } \\
\text { (age }<15 \text { years) }\end{array}$ & $\begin{array}{l}\text { Serum } \\
\text { analyses }\end{array}$ & $\begin{array}{l}\text { Skin prick tests were performed along } \\
\text { with serum total IgE, TEC, serum } \\
\text { ECP level, and ImmunoCAP } \\
\text { analysis for common allergens }\end{array}$ & $\begin{array}{l}\text { TEC, ECP, and total IgE levels were } \\
\text { significantly higher in the } \\
\text { non-responder group than in the } \\
\text { responder and control groups }\end{array}$ & $\begin{array}{l}\text { Yes } \\
\text { (Level III) }\end{array}$ \\
\hline $\begin{array}{l}\text { Mikolajczyk } \\
\text { et al. } 2019 \\
{[46 \bullet \bullet}\end{array}$ & $\begin{array}{c}N=842 \mathrm{AR} \text { children } \\
\text { and } 96 \text { controls }\end{array}$ & $\begin{array}{l}\text { \%EOSns. } \\
\text { MCT }\end{array}$ & $\begin{array}{l}\text { All patients underwent saccharin and } \\
\text { skin prick tests, nasal smear } \\
\text { eosinophilia, total and specific IgE } \\
\text { serum concentration, and MCT } \\
\text { measurement }\end{array}$ & $\begin{array}{l}\text { Nasal MCT was significantly longer } \\
\text { in AR patients than controls. } \\
\% \text { EOSns were significantly higher } \\
\text { in patients than controls. A weak } \\
\text { but significant correlation was } \\
\text { observed between \%EOSns and } \\
\text { MCT }\end{array}$ & $\begin{array}{l}\text { Yes } \\
\text { (Level III) }\end{array}$ \\
\hline $\begin{array}{l}\text { Brożek-Mądry } \\
\text { et al. } 2012 \\
\text { [47] }\end{array}$ & $\begin{array}{l}N=64 \text { patients with } \\
\text { chronic } \\
\text { rhinosinusitis } \\
\text { without polyps and } \\
30 \text { controls (age } \\
5-18 \text { years) }\end{array}$ & $\begin{array}{l}\text { Epithelial } \\
\text { cultures } \\
\text { (middle } \\
\text { meatal cells) }\end{array}$ & $\begin{array}{l}\text { Middle meatus culture and cytological } \\
\text { examination from the inferior nasal } \\
\text { concha and middle meatus }\end{array}$ & $\begin{array}{l}\text { The most common strains of bacteria } \\
\text { found in patients with CRS were } \\
\text { associated with a higher percentage } \\
\text { of eosinophils in cytology and high } \\
\text { prevalence in atopic patients }\end{array}$ & $\begin{array}{l}\text { Yes } \\
\text { (Level V) }\end{array}$ \\
\hline
\end{tabular}

$A R$, allergic rhinitis; $C R S$, chronic rhinosinusitis; $M C T$, mucociliary transport time: \%EOSns, percentage of eosinophils in nasal smear; TEC, total eosinophil count; $E C P$, serum eosinophil cationic protein

CRS, particularly in older children. Sedaghat et al. [55], analyzing a large series of 4044 pediatric cases observed AR in $26.9 \%$ children with CRS but their results were inconclusive because no comparison with control group was provided. Choi et al. [32] showed that age, atopy, AR, and asthma may be predisposing factors for pediatric CRS and recurrent RS. The authors proposed that specific evaluation for allergic diseases should be considered when managing chronic or recurrent RS. More recently, Anamika et al. [56 $\left.6^{\bullet}\right]$ demonstrated a positive skin prick test in $53 \%$ of the cases in a cohort of 110 children with CRS; moreover, those with atopy had higher mean Lund-Mackay endoscopic score and sinus and nasal quality of life survey score than non-atopic patients.

Huang et al. [57] attempted discrimination among different allergies and reported that mold allergy represents a significant risk factor for development of sinusitis, compared with nonmold allergy, in a case series of 413 children followed for 5 years. These data suggest that perennial allergy may be a stronger risk factor for CRS compared with seasonal allergy.

On the other hand, some studies suggested a lack of correlation between allergic disease and pediatric CRS. Leo et al. [58], in a report on 351 children affected by CRS, demonstrated that the prevalence of sensitization to aeroallergens was comparable with that of the general pediatric population. No clinical evidence could account for a higher rate of nasal congestion, nor a harsher clinical course, in allergic children [59]. Sedaghat et al. [51, 60] observed that pediatric patients with AR and CRS seem to have the same aeroallergen sensitivity profile compared with the general pediatric population with AR. Furthermore, the authors did not find a positive 
Table 4 Clinical evidences linking allergy to chronic rhinosinusitis in children

Clinical evidences linking allergy to risk of CRS in children

\begin{tabular}{|c|c|c|c|c|c|}
\hline $\begin{array}{l}\text { Author } \\
\text { Year } \\
\text { (ref) }\end{array}$ & Type of article & $\begin{array}{l}\text { No. of cases (mean } \\
\text { age) }\end{array}$ & Methods & Relevant results & $\begin{array}{l}\text { Association } \\
\text { (Level of } \\
\text { evidence) }\end{array}$ \\
\hline $\begin{array}{l}\text { Sedaghat } \\
\text { et al. } \\
2014 \\
\text { [55] }\end{array}$ & $\begin{array}{l}\text { Retrospective } \\
\text { analysis }\end{array}$ & $\begin{array}{l}N=4044 \text { children } \\
\quad \text { with CRS } \\
\quad(8.9 \text { years })\end{array}$ & $\begin{array}{l}\text { Retrospective review of children } \\
\text { diagnosed as uncomplicated CRS } \\
\text { by an otolaryngology or allergy } \\
\text { office evaluation }\end{array}$ & $\begin{array}{l}\text { Comorbidities observed in CRS children } \\
\text { were primary ciliary dyskinesia }(0.2 \%) \text {, } \\
\text { cystic fibrosis }(4.1 \%) \text {, immunologic } \\
\text { disorder }(12.3 \%), \text { and AR }(26.9 \%)\end{array}$ & $\begin{array}{l}\text { Inconclusive } \\
\text { (Level IV) }\end{array}$ \\
\hline $\begin{array}{l}\text { Choi et al. } \\
2012 \\
{[32]}\end{array}$ & $\begin{array}{l}\text { Prospective } \\
\text { study }\end{array}$ & $\begin{array}{l}N=296 \\
\quad(<13 \text { years }) \\
\text { with recurrent } \\
\quad \mathrm{RS}\end{array}$ & $\begin{array}{l}\text { To evaluate predisposing factors for } \\
\text { chronic and recurrent RS }\end{array}$ & $\begin{array}{l}\text { The prevalence of AR, atopy, and asthma } \\
\text { was significantly higher in patients with } \\
\text { CRS and recurrent RS than those with } \\
\text { acute and subacute RS }\end{array}$ & $\begin{array}{l}\text { Yes } \\
\text { (Level II) }\end{array}$ \\
\hline $\begin{array}{l}\text { Anamika } \\
\text { et al. } \\
2019 \\
{[56 \bullet]}\end{array}$ & $\begin{array}{l}\text { Cross-sectional } \\
\text { study. }\end{array}$ & $\begin{array}{l}N=110 \text { children } \\
\quad \text { with CRS } \\
\text { (7-18 years) }\end{array}$ & $\begin{array}{l}\text { To determine atopic profile of } \\
\text { children with CRS and impact of } \\
\text { atopic status on disease severity and } \\
\text { quality of life }\end{array}$ & $\begin{array}{l}\text { Positive skin prick test was present in } 52.7 \% \\
\text { of patients. Atopic CRS had a significant } \\
\text { higher mean Lund-Mackay endoscopic } \\
\text { score and symptoms scores than } \\
\text { non-atopic ones }\end{array}$ & $\begin{array}{l}\text { Yes } \\
\text { (Level IV) }\end{array}$ \\
\hline $\begin{array}{l}\text { Huang } \\
2000 \\
{[57]}\end{array}$ & $\begin{array}{l}\text { Prospective } \\
\text { observational } \\
\text { study }\end{array}$ & $\begin{array}{l}N=413 \text { RA } \\
\text { children. } \\
(3-15 \text { years })\end{array}$ & $\begin{array}{l}\text { To evaluate mold allergy as risk factor } \\
\text { for sinusitis. } \\
\text { The authors compared } 215 \text { PAR with } \\
\text { 198 SAR }\end{array}$ & $\begin{array}{l}\text { The prevalence of sinusitis was significantly } \\
\text { higher among patients with PAR than } \\
\text { among those with SAR regardless of age } \\
\text { or season; patients with mold allergy PAR } \\
\text { had a higher risk than those with non-mold } \\
\text { allergy }\end{array}$ & $\begin{array}{l}\text { Yes } \\
\text { (Level II) }\end{array}$ \\
\hline $\begin{array}{l}\text { Leo et al. } \\
\qquad 2007 \\
\quad[58]\end{array}$ & $\begin{array}{l}\text { Cross-sectional } \\
\text { study }\end{array}$ & $\begin{array}{l}N=351 \text { children } \\
\quad \text { with CRS } \\
\quad(5.23 \pm \\
2.11 \text { years })\end{array}$ & $\begin{array}{l}\text { CRS underwent allergen sensitization } \\
\text { work-up by skin prick test with } \\
\text { common inhalant allergens and } \\
\text { total IgE measurement }\end{array}$ & $\begin{array}{l}\text { Prevalence of sensitization to aeroallergens in } \\
\text { children with CRS is comparable with that } \\
\text { of the general pediatric population }\end{array}$ & $\begin{array}{l}\text { No } \\
\text { (Level IV) }\end{array}$ \\
\hline $\begin{array}{l}\text { Nathan } \\
\text { et al. } \\
2004 \\
{[62]}\end{array}$ & $\begin{array}{l}\text { Prospective } \\
\text { observational } \\
\text { study }\end{array}$ & $\begin{array}{l}N=114 \text { RA and } \\
\text { CRS (children } \\
\text { and adult) }\end{array}$ & $\begin{array}{l}\text { Patients were surveyed for global } \\
\text { symptoms and specific symptoms } \\
\text { related to the nose, sinuses, eyes, } \\
\text { and chest with the SOQ }\end{array}$ & $\begin{array}{l}\text { Immunotherapy is an effective treatment for } \\
\text { patients with sinus disease and allergic } \\
\text { rhinitis. }\end{array}$ & $\begin{array}{l}\text { Yes } \\
\text { (Level II) }\end{array}$ \\
\hline $\begin{array}{l}\text { Ramadan } \\
\quad \& \\
\text { Hiner- } \\
\text { man } \\
2006 \\
{[61]}\end{array}$ & $\begin{array}{l}\text { Prospective } \\
\text { observational } \\
\text { study }\end{array}$ & $\begin{array}{l}N=141 \text { patients } \\
\text { who underwent } \\
\text { ESS ( } 7 \text { years) }\end{array}$ & $\begin{array}{l}\text { To evaluate outcome of ESS at } 1 \text { year } \\
\text { after the operation }\end{array}$ & $\begin{array}{l}\text { Children with AR who were on treatment } \\
\text { before surgery had an } 84 \% \text { success rate } \\
\text { compared with } 62 \% \text { for those children } \\
\text { with non-treated AR by immunotherapy }\end{array}$ & $\begin{array}{l}\text { Yes } \\
\text { (Level II) }\end{array}$ \\
\hline $\begin{array}{l}\text { Kim et al. } \\
2005 \\
{[63]}\end{array}$ & $\begin{array}{l}\text { Retrospective } \\
\text { observational } \\
\text { study }\end{array}$ & $\begin{array}{l}N=97 \text { patients } \\
\text { (age range: } \\
5-15 \text { years) }\end{array}$ & $\begin{array}{l}\text { Retrospective analysis of long-term } \\
\text { success rates of ESS with respect to } \\
\text { several predisposing factors }\end{array}$ & $\begin{array}{l}\text { Multivariate logistic regression analysis } \\
\text { allergy was not correlated to poor } \\
\text { outcomes after pediatric ESS }\end{array}$ & $\begin{array}{l}\text { No } \\
\text { (Level IV) }\end{array}$ \\
\hline $\begin{array}{l}\text { El } \\
\text { Sharka- } \\
\text { wy } \\
2012 \\
{[64]}\end{array}$ & $\begin{array}{l}\text { Prospective } \\
\text { observational } \\
\text { study }\end{array}$ & $\begin{array}{l}N=87 \text { children } \\
\quad(45 \text { with nasal } \\
\text { allergy) } \\
\quad(\text { age } \leq 14)\end{array}$ & $\begin{array}{l}\text { To assess predictive factors of } \\
\text { outcome after ESS }\end{array}$ & $\begin{array}{l}\text { The success rate in CRS with nasal allergy } \\
\text { was } 87.5 \% \text {, and in CRS without nasal } \\
\text { allergy was } 85.7 \%\end{array}$ & $\begin{array}{l}\text { No } \\
\text { (Level II) }\end{array}$ \\
\hline $\begin{array}{l}\text { Lee et al. } \\
\qquad 2009 \\
{[66]}\end{array}$ & $\begin{array}{l}\text { Retrospective } \\
\text { analysis }\end{array}$ & $\begin{array}{l}N=53 \text { children } \\
\text { who underwent } \\
\text { FESS } \\
\quad \text { (age }<18 \text { years })\end{array}$ & $\begin{array}{l}\text { To investigate factors leading to } \\
\text { protracted nasal discharge after } \\
\text { pediatric endoscopic sinus surgery }\end{array}$ & $\begin{array}{l}\text { Blood eosinophil count did not differ } \\
\text { significantly between the "protracted" and } \\
\text { the "resolved" groups. On the other hand, } \\
\text { history of allergic rhinitis was more } \\
\text { frequently observed in the "protracted" } \\
\text { group }\end{array}$ & $\begin{array}{l}\text { Yes } \\
\text { (Level IV) }\end{array}$ \\
\hline $\begin{array}{l}\text { Wu et al. } \\
\qquad \begin{array}{l}2019 \\
{[67 \cdot]}\end{array}\end{array}$ & $\begin{array}{l}\text { Retrospective } \\
\text { analysis }\end{array}$ & $\begin{array}{l}N=188 \text { children } \\
\text { ESS for CRS }\end{array}$ & $\begin{array}{l}\text { To evaluate prognostic factors related } \\
\text { to revision surgery after ESS }\end{array}$ & $\begin{array}{l}\text { Patients with positive aeroallergen tests had } \\
\text { higher rates of CRS recurrence after ESS } \\
\text { and required revision surgery }\end{array}$ & $\begin{array}{l}\text { Yes } \\
\text { (Level IV) }\end{array}$ \\
\hline
\end{tabular}

$C R S$, chronic rhinosinusitis; $R S$, rhinosinusitis; $A R$, allergic rhinitis; $P A R$, perennial allergic rhinitis; $S A R$, seasonal allergic rhinitis; $S O Q$, sinusitis outcome questionnaire; ESS, endoscopic sinus surgery; FESS, functional endoscopic sinus surgery

association between the number of aeroallergen sensitivities and the presence of atopic comorbidities with the subsequent development of CRS, suggesting that the severity of atopy alone may not be positively predictive of CRS development. 


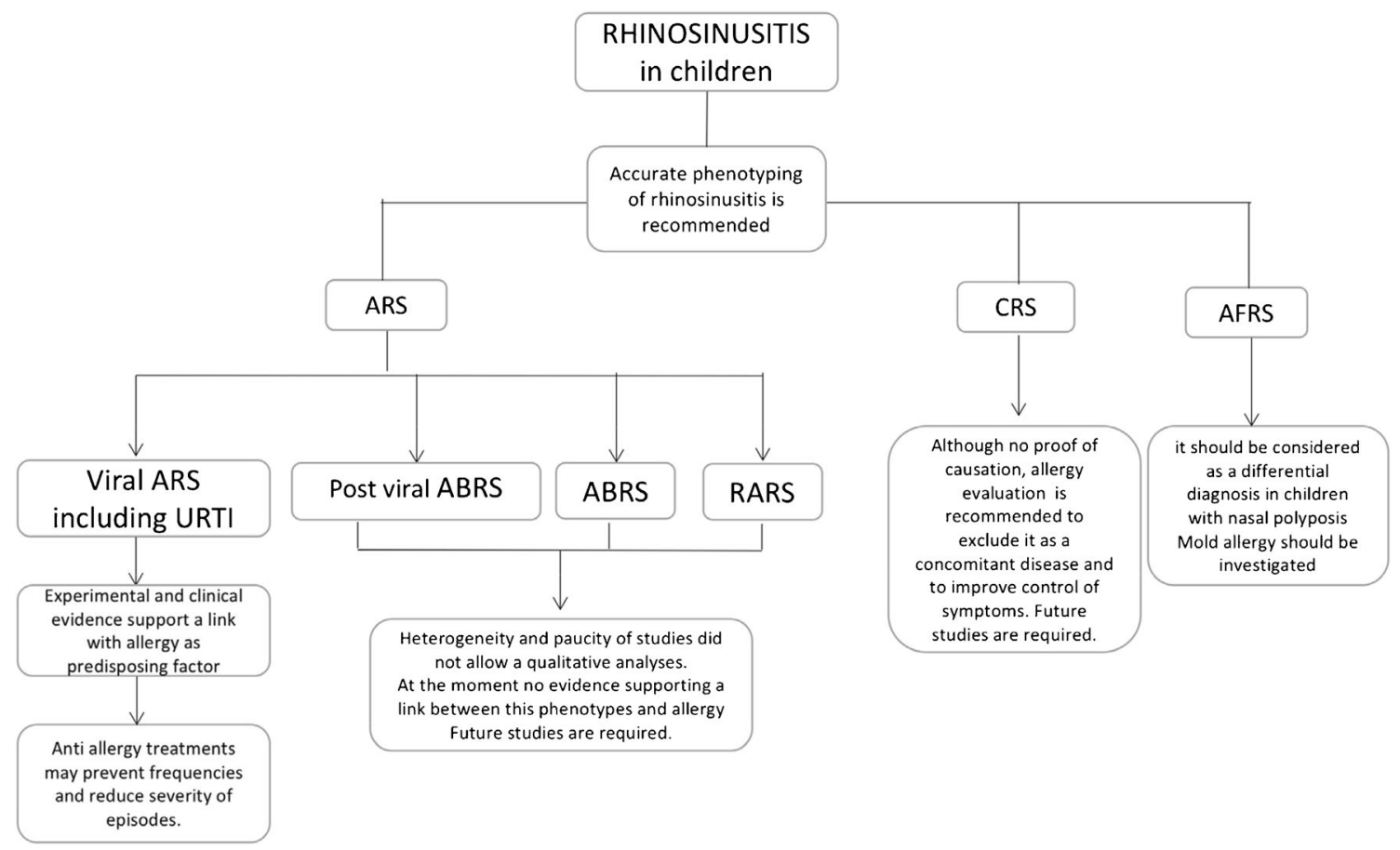

Fig. 2 Practical algorithm based on different phenotypes of rhinosinusitis in children. Abbreviations: ARS: acute rhinosinusitis; CRS chronic rhinosinusitis; URTI: upper respiratory tract infections; ABRS: acute

bacterial rhinosinusitis; RARS: recurrent acute rhinosinusitis; AFRS allergic fungal rhinosinusitis

These articles were not included in the qualitative analyses due to the type of article.

\section{Impact of Allergy on Outcome of Chronic Rhinosinusitis Treatment}

Ramadan and Hinerman [61], in a retrospective study, noted that children with AR underwent to endoscopic sinus surgery (ESS) do not have a poorer outcome respect non-allergic one. Nevertheless, children with AR who were on immunotherapy before surgery had an $84 \%$ success rate compared with $62 \%$ for those children with AR who were not treated $(p=0.022)$. Accordingly, Nathan et al. [62], using the sinusitis outcomes questionnaire (SOQ), demonstrated that immunotherapy was an effective treatment for patients with sinus disease and AR in both children and adults.

About surgery outcomes, Kim et al. [63] and El Sharkawy et al. [64] observed that functional endoscopic sinus surgery in children with CRS and AR does not provide significantly different results compared with children without AR, which is similar to what has been reported in adults [65]. On the contrary, in a study by Lee et al. [66], a significantly greater chance of protracted mucopurulent discharge after FESS was registered in patients with AR. The authors assumed that the inflammatory process of nasal allergy, which led to the development of CRS, probably impaired the postoperative wound healing by mucosal congestion, poor-functioning mucociliary clearance, and recurrent sneezing that placed pressure on the

denuded mucosa. An analogous conclusion was made by $\mathrm{Wu}$ et al. [67•] who demonstrated that pediatric patients with positive aeroallergen tests had higher rates of CRS recurrence after ESS and required revision surgery.

\section{Allergic Fungal Rhinosinusitis (AFRS) in Children}

AFRS is also present in the pediatric age group, and it should be considered a differential in children presenting with nasal polyposis along with the other causes like ciliary dysmotility disorders and cystic fibrosis [68]. There is paucity of data in literature regarding nature, clinical course, and its recurrence in children, and it was not possible to perform a qualitative analysis. Patro et al. [69] in a single center prospective study compared features of AFRS in children with adults. The authors concluded that AFRS was more aggressive in children with increased fungal load when compared with adults. The serum IgE levels were also found to be significantly higher in pediatric group, suggesting a higher fungal load, with increased sensitivity to fungal antigen in children. Typically, AFRS in children was less responsive to treatment, with increased recurrence rates.

\section{Conclusions}

$\mathrm{AR}$ is a common disease in childhood in industrialized countries, and it has a major impact on quality of life and healthcare 
resources. Improving the understanding of the pathophysiology of allergy and relationship with its comorbidities is important to correctly develop timed preventive measures as well as perform adequate monitoring and treatment of children with rhinitis. The correct management of allergic diseases can, in fact, decrease the inflammatory response and most likely lead to better control of comorbidities. We summarized in a practical algorithm our conclusions per phenotype of rhinosinusitis in order to elucidate when prompt accurate diagnosis and treatment of allergy is recommended (Fig. 2).

Our qualitative analyses demonstrated that there is clear evidence from the lab of a link between allergy and an overall impairment of mechanical and immunological defense function of nasal mucosa against viruses. Clinical studies support the hypothesis of a positive association between allergy and viral ARS/URTI, and only low-quality retrospective studies reached conflicting results. Proof of this is the existence of high-quality investigations showing that anti-allergy treatments may significantly decrease the number and severity of URTI including common colds. We did not find any articles investigating specifically the link between allergy and upper airway involvement by the new coronavirus in children.

Current experimental and clinical experience does not support an etiological link between allergy and post-viral rhinosinusitis, ABRS and RARS. At the moment, antiallergy treatments are not advised in these phenotypes even though well design high-quality studies are required to improve our knowledge in this field reaching firm conclusions.

Despite the growing knowledge related to allergy and CRS in children, it is not yet clear whether AR may promote CRS or if they only share a common pathway of pathogenesis. Even if AR has been positively associated with CRS in several experimental and clinical studies in children, conflicting results have also been reported, probably because of discrepancies in definitions of the disease processes for both CRS and AR and allergy testing methodologies. Researchers have used a variety of techniques to document the presence of sinusitis, such as patient surveys, radiography, CT scan, rhinoscopy, and routine physical examination, and therefore, the results may not reflect homogeneous populations. In addition, experimental studies and radiological assessment are often prevented by local ethical committees in the pediatric population, for comprehensible reasons. Furthermore, the evidence supports the hypothesis that CRS in children over the age of 13 seems to be more frequently associated with eosinophilic inflammation, whereas in younger patients with CRS, neutrophilic inflammation is often observed $[8,9]$. We did not find investigations analyzing the impact of allergy on CRS based on age, and we believe that more data from large epidemiological studies using explicit criteria is needed.

Although there is no proof of causation, several studies suggested that evaluation of underlying allergies in CRS children is equally recommended, at least to exclude allergy as a concomitant disease and to improve control of symptoms avoiding exposure to known allergens and promoting allergy therapies. Future studies are needed to confirm that antiallergy treatment may improve outcomes of endoscopic sinus surgery for CRS in children.

We finally believe that authors that will face with this topic in the near future should prefer prospective studies including multiple evaluations and paying particular attention to the different phenotypes of rhinosinusitis in children.

\section{Compliance with Ethical Standards}

Conflict of Interest This research did not receive any specific grant from funding agencies in the public, commercial, or not-for-profit sectors. The authors do not have any conflicts of interests to declare.

Human and Animal Rights and Informed Consent This article does not contain any studies with human or animal subjects performed by any of the authors.

\section{References}

Papers of particular interest, published recently, have been highlighted as:

- Of importance

• Of major importance

1. Meltzer EO, Hamilos DL. Rhinosinusitis diagnosis and management for the clinician: a synopsis of recent consensus guidelines. Mayo Clin Proc. 2011;86(5):427-43. https://doi.org/10.4065/mcp. 2010.0392.

2. Wood RA. Pediatric asthma. JAMA. 2002;288(6):745-7. https:// doi.org/10.1001/jama.288.6.745.

3. Bousquet J, Van Cauwenberge P, Khaltaev N, et al. Allergic rhinitis and its impact on asthma. JAMA. 2001;108(5):S147-334. https:// doi.org/10.1034/j.1398-9995.2002.23625.

4. Borish L. Allergic rhinitis: systemic inflammation and implications for management. J Allergy Clin Immunol. 2003;112(6):1021-31. https://doi.org/10.1016/j.jaci.2003.09.015.

5. Fokkens WJ, Lund VJ, Hopkins C, Hellings PW, Kern R, Reitsma $\mathrm{S}$, et al. European position paper on rhinosinusitis and nasal polyps 2020. Rhinology. 2020;58(Supplement 29):1-464. https://doi.org/ 10.4193/Rhin20.600.

6. Tan YSL, Hong CY, Chong PN, Tan ESL, Lew YJ, Lin RTP. Knowledge that upper respiratory tract infection resolves on its own is associated with more appropriate health-seeking behavior and antibiotic cognition. Singap Med J. 2006;47(6):518-24.

7. Garcia ML, Rey CC, Del Rosal Rabes T. Pediatric asthma and viral infection. Arch Bronconeumol. 2016;52(5):269-73. https://doi.org/ 10.1016/j.arbr.2016.03.010.

8. Larsen JM, Brix S, Thysen AH, Birch S, Rasmussen MA, Bisgaard H. Children with asthma by school age display aberrant immune responses to pathogenic airway bacteria as infants. J Allergy Clin Immunol. 2014;133(4):1008-13. https://doi.org/10.1016/j.jaci. 2014.01.010.

9. Parker D, Prince A. Innate immunity in the respiratory epithelium. Am J Respir Cell Mol Biol. 2011;45(2):189-201. https://doi.org/ 10.1165/rcmb.2011-0011RT. 
10. Waltl EE, Selb R, Eckl-Dorna J, Mueller CA, Cabauatan CR, Eiwegger T, et al. Betamethasone prevents human rhinovirus-and cigarette smoke-induced loss of respiratory epithelial barrier function. Sci Rep. 2018;8(1):1-10. https://doi.org/10.1038/s41598-01827022.

11. Steelant B, Farré R, Wawrzyniak P, Belmans J, Dekimpe E, Vanheel $\mathrm{H}$, et al. Impaired barrier function in patients with house dust mite-induced allergic rhinitis is accompanied by decreased occludin and zonula occludens-1 expression. J Allergy Clin Immunol. 2016;137(4):1043-53. https://doi.org/10.1016/j.jaci. 2015.10.050.

12. Steelant B, Seys SF, Van Gerven L, Van Woensel M, Farré R, Wawrzyniak P, et al. Histamine and T helper cytokine-driven epithelial barrier dysfunction in allergic rhinitis. J Allergy Clin Immunol. 2018;141(3):951-63. https://doi.org/10.1016/j.jaci. 2017.08.039

13. Ciprandi G, Buscaglia S, Pesce G, Villaggio B, Bagnasco M, Canonica GW. Allergic subjects express intercellular adhesion molecule-1 (ICAMA or CD54) on epithelial cells of conjunctiva after allergen challenge. J Allergy Clin Immunol. 1993;91(3):78392. https://doi.org/10.1016/0091-6749(93)90198.

14. Fasce L, Ciprandi G, Pronzato C, Cozzani S, Tosca MA, Grimaldi I, et al. Cetirizine reduces ICAM-I on epithelial cells during nasal minimal persistent inflammation in asymptomatic children with mite-allergic asthma. Int Arch Allergy Immunol. 1996;109(3): 272-6. https://doi.org/10.1159/000237249.

15. Baraldo S, Contoli M, Bazzan E, Turato G, Padovani A, Marku B, et al. Deficient antiviral immune responses in childhood: distinct roles of atopy and asthma. J Allergy Clin Immunol. 2012;130(6): 1307-14. https://doi.org/10.1016/j.jaci.2012.08.005.

16. Głobińska A, Pawełczyk M, Piechota-Polańczyk A, OlszewskaZiąber A, Moskwa S, Mikołajczyk A, et al. Impaired virus replication and decreased innate immune responses to viral infections in nasal epithelial cells from patients with allergic rhinitis. Clin Exp Immunol. 2017;187(1):100-12. https://doi.org/10.1111/cei.12869.

17. Fenoglio D, Ferrera A, Ferrera F, Sormani MP, Di Gioacchino M, Ciprandi G. Patients with allergic rhinitis show an allergen-specific interferon-gamma defect. Eur J Inflamm. 2008;6(2):87-91. https:// doi.org/10.1177/1721727X0800600206.

18. Teach SJ, Gill MA, Togias A, Sorkness CA, Arbes SJ Jr, Calatroni $A$, et al. Preseasonal treatment with either omalizumab or an inhaled corticosteroid boost to prevent fall asthma exacerbations. J Allergy Clin Immunol. 2015;136(6):1476-85. https://doi.org/10.1016/j. jaci.2015.09.008.

19. Karevold G, Kvestad E, Nafstad P, Kvaerner KJ. Respiratory infections in schoolchildren: co-morbidity and risk factors. Arch Dis Child. 2006;91(5):391-5. https://doi.org/10.1136/adc.2005. 083881.

20. Ciprandi G, Tosca MA, Fasce L. Allergic children have more numerous and severe respiratory infections than non-allergic children. Pediatr Allergy Immunol. 2006;17(5):389-91. https://doi.org/10. 1111/j.1399-3038.2006.00413.

21. Kværner KJ, Tambs K, Harris JR, Mair IW, Magnus P. Otitis media: relationship to tonsillitis, sinusitis and atopic diseases. Int $\mathrm{J}$ Pediatr Otorhinolaryngol. 1996;35(2):127-41. https://doi.org/10. 1016/0165-5876(95)01299-0.

22. Sütçü M, Acar M, Aktürk H, Hançerli-Törün S, Salman N, Somer A. Recognizing immunodeficiency in children with recurrent infections: What are the predictive factors? The Turk J Pediatr. 2016;58(6):609-15. https://doi.org/10.24953/turkjped.2016.06. 006.

23. Ciprandi G, Tosca M, Passalacqua G, Canonica GW, Ricca V, Landi M. Continuous antihistamine treatment controls allergic inflammation and reduces respiratory morbidity in children with mite allergy. Allergy. 1999;54(4):358-65. https://doi.org/10.1034/j. 1398-9995.1999.00920.x.
24.• Barberi S, Bernardo L, D'Auria E, Ferrara F, Tosi S, Incorvaia C, et al. Allergen immunotherapy and respiratory infections in children: an encouraging experience. Minerva Pediatr. 2018;70(1):1-4. https://doi.org/10.23736/s0026-4946.16.04394-2 The authors demonstrated that 3 year high-dose HDM-SLIT significantly reduced respiratory infections in children with allergic rhinitis.

25. Barberi S, Ciprandi G, Verduci E. Effect of high-dose sublingual immunotherapy on respiratory infections in children allergic to house dust mite. Asia Pac Allergy. 2015;5(3):163-9. https://doi. org/10.5415/apallergy.2015.5.3.163.

26. Chow AW, Benninger MS, Brook I, Brozek JL, Goldstein EJ, Hicks LA, et al. Infectious Diseases Society of America. IDSA clinical practice guideline for acute bacterial rhinosinusitis in children and adults. Clin Infect Dis. 2012;54(8):72-112. https://doi. org/10.1093/cid/cis370.

27. Lin SW, Wang YH, Lee MY, Ku MS, Sun HL, Lu KH, et al. Clinical spectrum of acute rhinosinusitis among atopic and nonatopic children in Taiwan. Int J Pediatr Otorhinolaryngol. 2012;76(1):70-5. https://doi.org/10.1016/j.ijporl.2011.10.002.

28. Holzmann D, Willi U, Nadal D. Allergic rhinitis as a risk factor for orbital complication of acute rhinosinusitis in children. Am J Rhinol. 2001;15(6):387-90. https://doi.org/10.1177/ 194589240101500606.

29. Alho OP, Karttunen TJ, Karttunen R, Tuokko H, Koskela M, Suramo I, et al. Subjects with allergic rhinitis show signs of more severely impaired paranasal sinus functioning during viral colds than nonallergic subjects. Allergy. 2003;58(8):767-71. https://doi. org/10.1034/j.1398-9995.2003.00252.

30. Lin SW, Wang SK, Lu MC, Wang CL, Koo M. Acute rhinosinusitis among pediatric patients with allergic rhinitis: A nationwide, population-based cohort study. PLoS One. 2019;14(2). https://doi.org/10.1371/journal.pone.0211547.

31. Leo G, Incorvaia C, Cazzavillan A, Consonni D, Zuccotti GV. Could seasonal allergy be a risk factor for acute rhinosinusitis in children? J Laryngol Otol. 2018;132(2):150-3. https://doi.org/10. 1017/S0022215118000038.

32. Choi SH, Han MY, Ahn YM, Park YM, Kim CK, Kim HH, et al. Predisposing factors associated with chronic and recurrent rhinosinusitis in childhood. Allergy, Asthma Immunol Res. 2012;4(2):80-4. https://doi.org/10.4168/aair.2012.4.2.80.

33. Veskitkul J, Vichyanond P, Pacharn P, Visitsunthorn N, Jirapongsananuruk O. Clinical characteristics of recurrent acute rhinosinusitis in children. Asian Pac J Allergy Immunol. 2015:33(4):276-80. https://doi.org/10.12932/AP0591.33.4.2015.

34. Brożek JL, Bousquet J, Agache I, Agarwal A, Bachert C, BosnicAnticevich S, et al. Allergic Rhinitis and its Impact on Asthma (ARIA) guidelines-2016 revision. J Allergy Clin Immunol. 2017;140(4):950-8. https://doi.org/10.1016/j.jaci.2017.03.050.

35. Veling MC. The role of allergy in pediatric rhinosinusitis. Curr Opin Otolaryngol Head Neck Surg. 2013;21(3):271-6. https://doi. org/10.1097/MOO.0b013e32835fb399.

36. Chan KH, Abzug MJ, Coffinet L, Simoes EA, Cool C, Liu AH. Chronic rhinosinusitis in young children differs from adults: a histopathology study. J Pediatr. 2004;144(2):206-12. https://doi.org/ 10.1016/j.jpeds.2003.11.009.

37. Berger G, Kogan T, Paker M, Berger-Achituv S, Ebner Y. Pediatric chronic rhinosinusitis histopathology: differences and similarities with the adult form. Otolaryngol Head Neck Surg. 2011;144(1): 85-90. https://doi.org/10.1177/0194599810390443.

38. De Corso E, Baroni S, Lucidi D, Battista M, Romanello M, Autilio C, et al. Nasal lavage levels of granulocyte-macrophage colonystimulating factor and chronic nasal hypereosinophilia. Int Forum Allergy Rhinol. 2015;5(6):557-62. https://doi.org/10.1002/alr. 21519.

39. De Corso E, Baroni S, Romitelli F, Luca L, Di Nardo W, Passali GC, et al. Nasal lavage CCL24 levels correlate with eosinophils 
trafficking and symptoms in chronic sino-nasal eosinophilic inflammation. Rhinology. 2011;49(2):174-9. https://doi.org/10.4193/ rhino10.133.

40. De Corso E, Lucidi D, Battista M, Romanello M, De Vita C, Baroni $\mathrm{S}$, et al. Prognostic value of nasal cytology and clinical factors in nasal polyps development in patients at risk: can the beginning predict the end? Int Forum Allergy Rhinol. 2017;7(9):861-7. https://doi.org/10.1002/alr.21979.

41. De Corso E, Baroni S, Battista M, Romanello M, Penitente R, Di Nardo W, et al. Nasal fluid release of eotaxin-3 and eotaxin-2 in persistent sinonasal eosinophilic inflammation. Int Forum Allergy Rhinol. 2014;4:617-24. https://doi.org/10.1002/alr.21348.

42. De Corso E, Anzivino R, Galli J, Baroni S, Di Nardo W, De Vita C, et al. Antileukotrienes improve naso-ocular symptoms and biomarkers in patients with NARES and asthma. Laryngoscope. 2019;129(3):551-7. https://doi.org/10.1002/lary.27576.

43. Chawes BL. Upper and lower airway pathology in young children with allergic and non-allergic rhinitis. Dan Med Bull. 2011;58(5): B4278.

44. Blair C, Nelson M, Thompson K, Boonlayangoor S, Haney L, Gabr $\mathrm{U}$, et al. Allergic inflammation enhances bacterial sinusitis in mice. J Allergy Clin Immunol. 2001;108(3):424-9. https://doi.org/10. 1067/mai.2001.117793.

45. Shin YH, Kim HS, Lee EK, Kim YJ, Lee HS, Jang PS, et al. Eosinophil related markers and total immunoglobulin $\mathrm{E}$ as a predictive marker for antibiotics response in chronic rhinosinusitis: a case-control study. Ann Saudi Med. 2015;35(4):312-7. https://doi. org/10.5144/0256-4947.2015.312.

46.• Mikolajczyk M, Janukowicz K, Majewska E, Baj Z. Impact of Allergic Rhinitis on Nasal Mucociliary Clearance Time in Children. Int Arch Allergy Immunol. 2019;179(4):297-303. https://doi.org/10.1159/000499740 This is a case control study on a large series demonstrating that percentage of eosinophils in nasal smear was significantly higher in patients than controls. Accordingly muco-ciliary transport was significantly longer in allergic rhinitis patients than non-allergic ones.

47. Brożek-Mądry E, Chmielik LP, Gałązka A, Rogulska J, Frąckiewicz M, Biejat A. Chronic rhinosinusitis in childrenbacteriological analysis in terms of cytological examination. Int $\mathrm{J}$ Pediatr Otorhinolaryngol. 2012;76(4):512-22. https://doi.org/10. 1016/j.ijporl.2012.01.008.

48. Bachert C, Gevaert P, Van Cauwenberge P. Staphylococcus aureus enterotoxins: a key in airway disease? Allergy. 2002;57(6):480-7. https://doi.org/10.1034/j.1398-9995.2002.02156.x.

49. Philpott CM, Erskine S, Hopkins C, Kumar N, Anari S, Kara N, et al. Prevalence of asthma, aspirin sensitivity and allergy in chronic rhinosinusitis: data from the UK National Chronic Rhinosinusitis Epidemiology Study. Respir Res. 2018;19(1):129. https://doi.org/ 10.1186/s12931-018-0823-y.

50. Del Gaudio JM, Loftus PA, Hamizan AW, Harvey RJ, Wise SK. Central compartment atopic disease. Am J Rhinol Allergy. 2017;31(4):228-34. https://doi.org/10.2500/ajra.2017.31.4443.

51. Sedaghat AR, Phipatanakul W, Cunningham MJ. Atopy and the development of chronic rhinosinusitis in children with allergic rhinitis. J Allergy Clin Immunol Pract. 2013;6(1):689-691.e2.

52. Tantimongkolsuk C, Pornrattanarungsee S, Chiewvit P, Visitsunthorn N, Ungkanont K, Vichyanond P. Pediatric sinusitis: symptom profiles with associated atopic conditions. J Med Assoc Thail. 2005;88(Suppl 8):S149-55.

53. Chandy Z, Ference E, Lee JT. Clinical Guidelines on Chronic Rhinosinusitis in Children. Curr Allergy Asthma Rep. 2019;19(2):14. https://doi.org/10.1007/s11882-019-0845-7.

54. Brietzke SE, Shin JJ, Choi S, Lee JT, Parikh SR, Pena M, et al. Clinical consensus statement: pediatric chronic rhinosinusitis. Otolaryngol Head Neck Surg. 2014;151(4):542-53. https://doi. org/10.1177/0194599814549302.
55. Sedaghat AR, Phipatanakul W, Cunningham MJ. Prevalence of and associations with allergic rhinitis in children with chronic rhinosinusitis. Int J Pediatr Otorhinolaryngol. 2014;78(2):343-7. https://doi.org/10.1016/j.ijporl.2013.12.006.

56. Anamika A, Chakravarti A, Kumar R. Atopy and quality of life in pediatric chronic rhinosinusitis. Am J Rhinol Allergy. 2019;33(5): 586-90. https://doi.org/10.1177/1945892419854266 The authors demonstrated that atopic children with chronic rhinosinusitis had a significant higher mean Lund-Mackay endoscopic score and symptoms scores than non-atopic ones.

57. Huang SW. The risk of sinusitis in children with allergic rhinitis. Allergy Asthma Proc. 2000;21:85-8. https://doi.org/10.2500/ 108854100778250905.

58. Leo G, Piacentini E, Incorvaia C, Consonni D, Frati F. Chronic rhinosinusitis and allergy. Pediatr Allergy Immunol. 2007;18:19 21. https://doi.org/10.1111/j.1399-3038.2007.00626.x|.

59. Gelardi M, Marchisio P, Caimmi D, Incorvaia C, Albertario G, Bianchini S, et al. Pathophysiology, favoring factors, and associated disorders in otorhinosinusology. Pediatr Allergy Immunol. 2012;23:5-16. https://doi.org/10.1111/j.1399-3038.2012.01323.

60. Sedaghat AR, Phipatanakul W, Cunningham MJ. Characterization of aeroallergen sensitivities in children with allergic rhinitis and chronic rhinosinusitis. Allergy Rhinol (Providence). 2014;5(3) ar2014. https://doi.org/10.2500/ar.2014.5.0102.

61. Ramadan HH, Hinerman RA. Outcome of endoscopic sinus surgery in children with allergic rhinitis. Am J Rhinol. 2006;20(4): 438-40. https://doi.org/10.2500/ajr.2006.20.2879.

62. Nathan RA, Santilli J, Rockwell W, Glassheim J. Effectiveness of immunotherapy for recurring sinusitis associated with allergic rhinitis as assessed by the Sinusitis Outcomes Questionnaire. Ann Allergy Asthma Immunol. 2004;92(6):668-72. https://doi.org/10. 1016/S1081-1206(10)61435-4.

63. Kim HY, Dhong HJ, Chung SK, Chung YJ, Min JY. Prognostic factors of pediatric endoscopic sinus surgery. Int $\mathrm{J}$ Pediatr Otorhinolaryngol. 2005;69(11):1535-9. https://doi.org/10.1016/j. ijporl.2005.04.010.

64. El Sharkawy AA, Elmorsy SM, Eladl HM. Functional endoscopic sinus surgery in children: predictive factors of outcome. Eur Arch Otorhinolaryngol. 2012;269(1):107-11. https://doi.org/10.1007/ s00405-011-1680-1.

65. Robinson S, Douglas R, Wormald PJ. The relationship between atopy and chronic rhinosinusitis. Am J Rhinol. 2006;20(6):625-8. https://doi.org/10.2500/ajr.2006.20.2907.

66. Lee TJ, Liang CW, Chang PH, Huang CC. Risk factors for protracted sinusitis in pediatrics after endoscopic sinus surgery. Auris Nasus Larynx. 2009;36(6):655-60. https://doi.org/10.1016/ j.anl.2009.02.008.

67. Wu PW, Huang CC, Yang SW, Huang Y, Huang CC, Chang PH, et al. Endoscopic sinus surgery for pediatric patients: prognostic factors related to revision surgery. Laryngoscope. 2020;130(4): 1051-5. https://doi.org/10.1002/lary.28106 The authors demonstrated that pediatric patients with positive aeroallergen tests had higher rates of CRS recurrence after ESS and required revision surgery.

68. Thorp BD, McKinney KA, Rose AS, Ebert CS. Allergic fungal sinusitis in children. Otolaryngol Clin N Am. 2012;45(3):631-42. https://doi.org/10.1016/j.otc.2012.03.003.

69. Patro SK, Verma RK, Panda NK, Chakrabarti A. Understanding paediatric allergic fungal sinusitis: is it more aggressive? Int $\mathrm{J}$ Pediatr Otorhinolaryngol. 2015;79(11):1876-80. https://doi.org/ 10.1016/j.ijporl.2015.08.032.

Publisher's Note Springer Nature remains neutral with regard to jurisdictional claims in published maps and institutional affiliations. 